\title{
THE PROBLEM OF INTRA-ALLIANCE ECONOMIC COOPERATION ANT MILITARY ASSISTANCE
}

Prof. Dr. Ahmet Demir

\section{I - INTRODUCTION}

It has been about more than thirty years since NATO was cstablished. These thirty years, in the second half of our century, is a period in which numerous international affairs have taken place and many of the developments have been still continuing with their multidimensional effects.

It might have been better to count the events or show the chain of the developments in order to better evaluate the time dimension of NATO. However some major ones will satisfy our needs just to mention the dynamics of the past thirty years. In that respect, the number of the independent states in the world had been tripled since 1949. Many of the nations had had internal transformations. The world population was almost doubled. Changes and/or developments in the fields of electronics, nuclear physics, aerospace, communication, etc. as well as in the foundations of basic science constitute the scientific facet of the last three decades.

The new discoveries and developments in science had been quickly integrated with the military science and introduced new war tecnology, methode and tactics and thereby the concepts of strategy and geopolitics have changed greatly.

In the area of national and international economics there had been unpredicted and unexpected developments particularly with respect to the prices of raw material and energy, within last ten years. Fast and constant increases in those prices caused the rate of economic development and/or growth to slow down and the high rate, mostly doubledigit inflation had become the permanent feature of many economics: 
Another basic issue in the last three decades is related to the population and natural resources. The balance between the two has been continuously deteriorating. Therefore protectional measures to conserve the nature and to use the natural resources rationally have increasingly drawn the attention of economists as well as politicians.

In sum, in the last thirty years the world had unpreceded political economic, social and cultural changes and/or developments. NATO, within the above perspective of the last three decades, has survived and even-got stronger compared to preceding military allies in the past. Further it seems that NATO, as being an alliance among the Western democratic nations, respectful to human rights, will successfully survive and develop with mutual understanding and trust. The common efforts to save the national sovereignty in the alliance as well as the co-existence in peace with others shows that NATO has a strong foundation to create a peaceful and prosperous world of future.

There is no doubts that, in the last thirty years, NATO had some internal problems. The resignation of France from the military responsibilities, the Cyprus issue between Turkey and Greece and the problem of fishing rights between U.K. and Iceland have been outstanding ones deserving ultimate solutions. Besides these heavily political issues, there have been some other economic, financial and technical disagreements among the members; such as the formulation of military aids, the distrbution of the economic burden of the defense expenditures, the coordination of the programmes of arms production, including the efforts of research and development, and standardization. The organization, with a dynamic structure has been continuously working on such issues and reviewing the alternatives for a final resolution and that forming special organs if required by the problem.

We, as an applied economist, have done a study - survey on these major issues, mainly dealing with the problems and alternatives in economic cooperation and military aids among the member countries. The findings of the research have been evaluated and some proposals have been made.

We shall follow a chronological order, within the above framework, in our approach to the stated problems. This will certainly make the illustration more understandable from the historical point of view. 


\section{II - HISTORICAL PERSPECTIVE}

Towards the end of the Second World War, the representatives of some fifty nations met in San Fransisco and signed the Charter of the United Nations, on June 26, 1945.

That was imagined as a light of hope for the future in making collaborated efforts to preserve the peace in the world after six years of devastating war. It was the time to restore the ruins, to built international cooperation for progression in peace. But, although the U.S.A., Canada and the U.K., allies with Soviet Union during the war years, had withdrawn most of their military forces from the continent after the war, the Soviet Union, other victorious nation, had not show any sign of withdrawal from the occupied lands in Europe. Furthermore, the Soviet Union was keeping on about four million armed forces and operating the war industry at fully capacity.

While Western victorious nations, have not demanded any piece of land from the defeated nations, the Soviet Union, on the contrary, has occupied more than half million $\mathrm{km}^{2}$ with more than 23 million inhabitants in the Eastern Europe, interfered with the internal affairs of her neighboring countries and in some cases helped the minority communist parties come to the power.

Towards the end of 1940's, the political and economic situation in Western Europe and the Balkans was not optimistic. The Western European nations could not seem to overcome the economic and financial issues that had been created by war. The Balkanic nations, except Turkey and Greece had been put in a position of satellite with the Soviet Union. Even in Greece, the communists were making advances and rebelling against the government and weakening the regime politically as well as economically. Turkey, although she had not activelly involved in the war, was in economic difficulty. Furthermore the Soviet Union was in a fundemental dispute with Turkey after the refusal of her demands regarding territorial claims on a piece of land in Eastern Anatolia and the Straits. In sum, the Western Europe, Greece and Turkey were under the strong pressure of Soviet Imperialism.

However, the leader of the Western nations were not late in evaluating the trends of political developments right after the war. For instance, W. Churchill had warned the U.S. against a Soviet occupation in Germany right after the surrender. 
The recovery in the Western Europe was advancing relatively slow due to the heavy economic and financial problems. However, they have tried hard to strengthen their defense. In fact, the U.K. and France signed a Treaty of Alliance for fifty years and an agreement for Mutual Assistance in Dunkirk in 1947, March 4.

In the meantime, the U.S. was also concerned about the Soviet expansion in Europe and the Balkans. Therefore, upon President Truman's proposal, the Congress had signed a bill for about $\$ 400$ million military and economic aid to Turkey and Greece. The situation in the Western Europe was no better than these two countries and an aid pack was desparately needed. The Secratary of State, G.C. Marshall, in his speech at Harvard University on June 5, 1947, had defended the idea of aid to Europe for a recovery. The Congress had accepted the resolution and signed the bill for $\$ 10$ billion aid to Europe in a short time. The Marshall Aid was indeed economic in nature. Turkey and Greece also received partial assistance from this pack.

Parallel to the huge Marshall aid program and following economic recovery, the Western European nations had also increased the intensity of political cooperation against Soviet pressure and influence. In that respect, the Brusselles Treaty, a comprehensive form of Dunkirk Agreements in some respect, has been signed by the U.K., France, Holland, Belgium and Luxembourg on March 17, 1948.

The Brusselles Treaty has provided not only economic, social and cultural collaborations among the members but also a collective defense for fifty years. After the Treaty, the defense of Western Europe had gained a special attention and vitality. In the U.S., the idea of a defense agreement for the North Atlantic Region found strong supporters from the military persons, politicians as well as academicians.

Finally, the representatives from the U.S., Canada, Brusselles Treaty members and from some other European nations have signed the NATO Agreement on April 4, 1949 after long meetings and discussions. (Turkey and Greece have participated in on October 22, 1951 and West Germany became member on October 23, 1954.)

The Treaty consists of a preamble and fourteen articles. The second and the third articles are the most related ones to our study. According to these articles, the members will increase their military 
forces to defend themselves and the Treaty itself as well as they will work on eliminating the differences and cooperating economically. The interpretation and application in later years show that the economic cooperation among the members cover not only the "normal" economic activities but also to overcome the economic problems created by the defense expense and to distribute justfully the burden of defense. This point has been accentuated in the following manner:

"The North Atlantic Treaty is essentially a framework for very broad cooperation between its signatories. It is not only a military alliance formed to prevent aggression or to repel it should the need arise. It also provides for joint permanent action in the political, economic and social fields."

The major factor in the formation of NATO as a defense treaty has been the Soviet influence and pressure in Europe and the Balkans as we have explained so far. From that respect, the organization, right after the establishment was formed the North Atlantic Council which is the most important organ, and the subject of military cooperation and organization received the priority at the outset. However, by the time, it has been realized that an efficient political, economic and financial organization and cooperation were the integral parts of a strong defense alliance. For these purposes special agencies have been formed within the Treaty. (It has no use at least for, our purpose to give the agencies established in chronological order. Therefore a few charts will fulfil the need; see Charts I, II and III).

\section{A - Mutual Military Assistance Program for Defense}

The five signatories of the Brusselles Agreement have officially demanded military and financial aid from the U.S. on the next day they have signed the North Atlantic Treaty. Their demand has been found reasonable and acceptable by President Truman. He referred the subject to the Congress. ${ }^{2}$ After a long debate over the European demand, the Congress passed the Bill of Mutual Military Aid on October 6, 1949. President Truman has appointed a director for managing the Aid on October 7, 1949 and the next month an office

I NATO-FACTS ABOUT THE NORTH ATLANTIC TREATY ORGANIZATION, NATO Information Service, Paris, 1985, p., 16.

2 Lord Ismay; OTAN 1949-1954, LES CINQ PREMIERES ANNEES, Bosch-Utrecht, pp. 24-25. 
at the Department of Defense has been formed to run and coordinate the military equipment aid to Europe. ${ }^{3}$ The aid program has been first activated by the Agreement signed by eight European NATO allies and the U.S. on January 27, 1950 and the American military equipment had started to flow to Europe in the following March. The aids given by the U.S. to European allies in accordance with the Agreement were actually conditional grants in the initial years in the sense that the grant - receiving allies were not able to use these military equipment for other than the NATO purposes. In that sense, the right of use of these equipment was delivered to the Europeans by the Agreement of January 1950. In some cases these equipment was granted by the Lease Land Act.

Chart : I

THE ORGANIZATION IN DECEMBER 1949

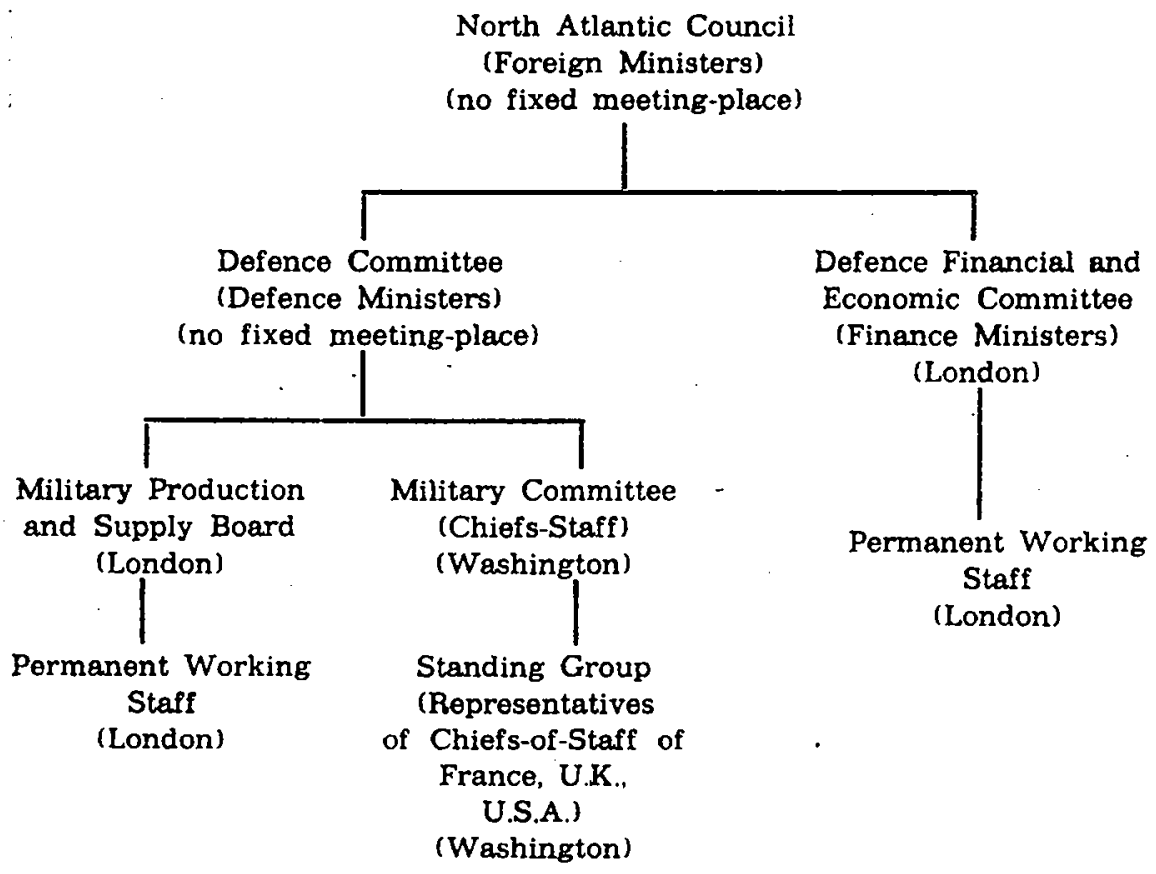

Source : Robert S. Jordan; THE NATO INTERNATIONAL STAFF/SECRETERIAT 1952-1957, Oxford University Press, London, 1867, p, 21.

3 Ibid; p. 25. 
Chart : II

THE ORGANIZATION IN MAY 1951

North Atlantic Council

(Council of Governments on which the

Foreign, Defence and Finance Ministers

met periodically)

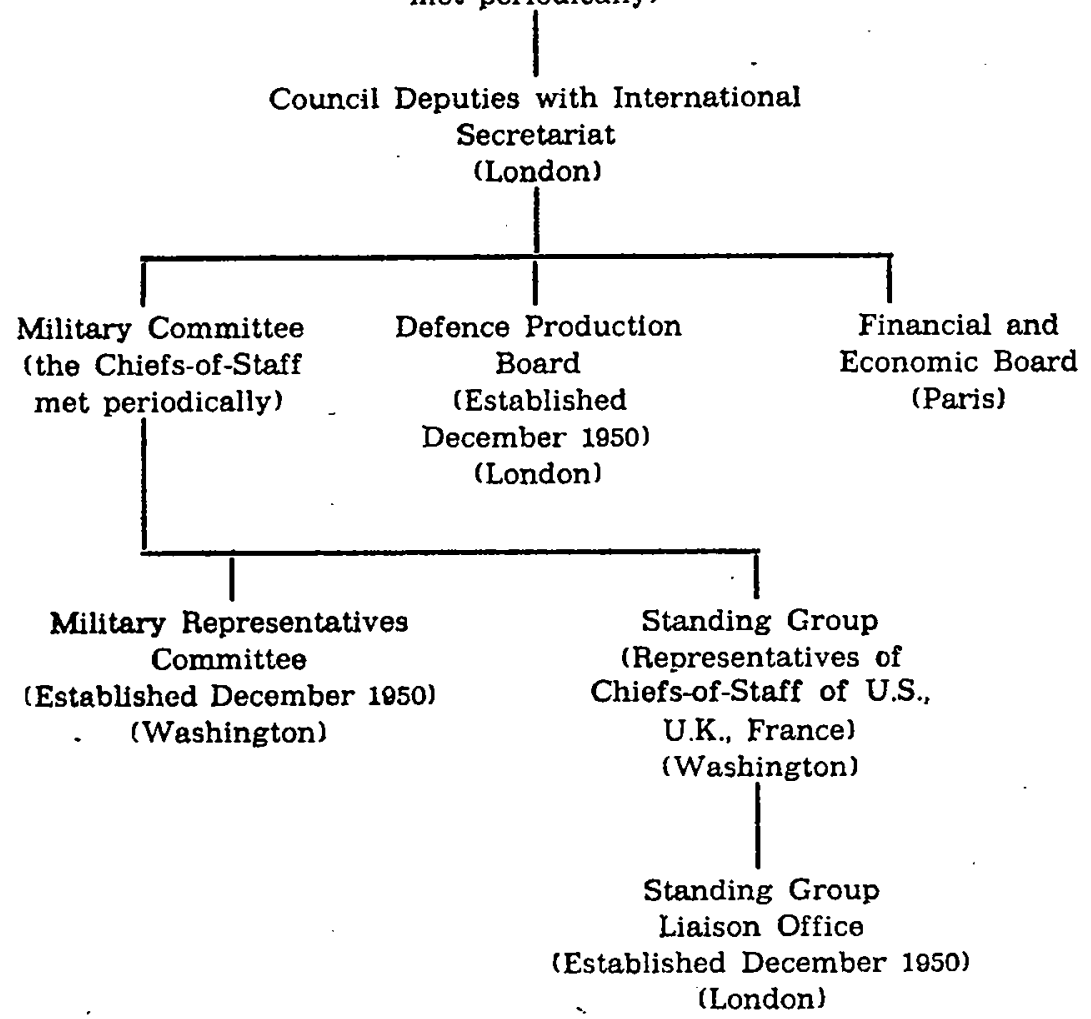

Source : Ibid, p. 25.

The military assistance funded by the U.S. to meet the demand of European allies usually was in the form of end items or off-shore. The off-shore aid is defined as "system whereby the United States buys equipment in various European countries with funds from its Mutual Defense Assistance Program and gives it to one of the allied countries for equipping its armed forces." 4 In time there was also a continous increase in the number of bilateral agreements between the U.S. and other nations.

Il also worths mentioning the military assistance of Canada. It was initially in the form of donating the British-made arms and

1 NATO, FACTS ABOUT THE NORTH TREATY ORGANIZATION, Paris, 1865, p. 16. 


\section{Principal Committees of the Councl}

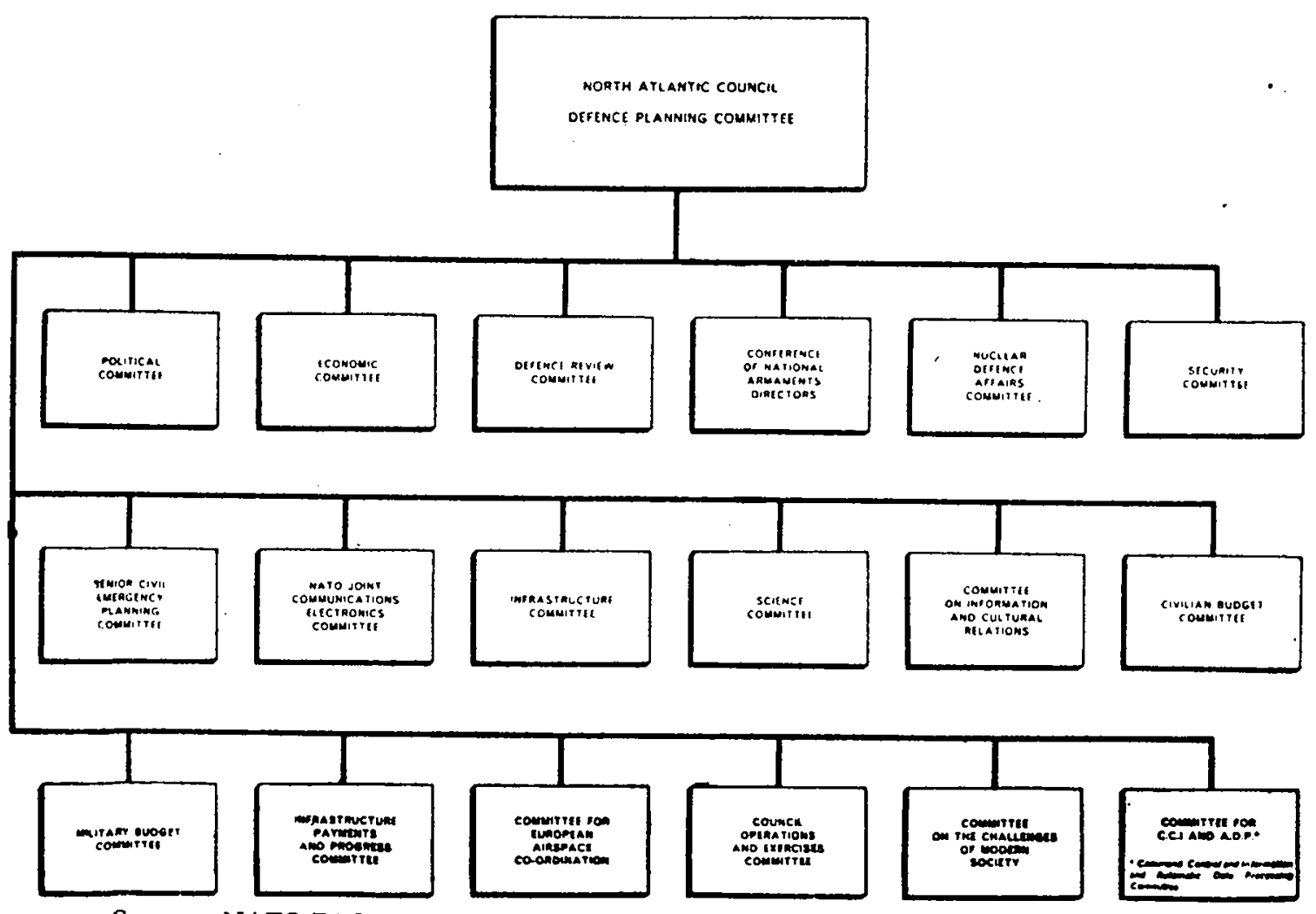

Source : NATO-FACTS ABOUT THE NORTH ATLANTIC TREATY ORGANIZATION, NATO Information Service, Paris, 1965, p. 51. 
equipment to the European allies while equipping its armed forces with the modern U.S. weapons and equipment. Beside this sort of assistance, Canada has given some of the Sabre war planes, which were produced in Canada with American license, to European members. In addition, a large number of air force pilots from the European allies had been trained in Canada on grant- aid program.

Greece and Turkey, the late members of NATO, had benefited in large amount from the Mutual Defense Asistance Program.

An important point is that the military assistance, initially led by the U.S. and Canada, has changed its characteristics and forms by time. European economic recovery was the major cause of this transformation since after the recovery the European allies were able to participate and increase their shares in the mutual defense budget. Undoubtedly the decrease in grant-in-aids to the Europeans by the U.S. have been parallel to the developments in Europe. However, the military equipment sales to Europe on credit continued. Furthermore, West European, specially continental countries, after the recovery have experienced a high rate of economic development and technical advance. As a result of these progressions they have cooperated in producing arms and equipment initially with patent rights and later on their own. Turkey and Greece with their limited capacities also participated in some of the projects.

It would be better and enlightening to classify the defense assistance among the NATO allies with respect to their nature and purposes. This will also help to the final evaluation at the end of our research.

\section{B - The forms of Mutual Military Assistance}

From the explanations so far, we understand that the Mutual Military Assistance has been stemmed (originated) from the strategic needs. That is, some important activities can not be accomplished by some nations due to their financial, economic or technical disabilities, in such cases, an ally can agree in providing the required equipment or arms for other ally or allies within the Treaty.

It it possible to classify these aids into three broad categories with respect to the forms of acquisation and the usage.

\section{1 - Military Aid Proper}

This assistance, in practice, consists of the material equipment and supplies, such as artillary, tanks, aircrafts, armoured personnel 
carries, cars, ammunitions etc., needed for the military forces of NATO allies in Europe. This sort of U.S. assistance amounted about $\$ 17$ billion until 1963. Part of this aid between 1953-1958 was in the form of "off-shore" assistance and bought from European countries but major part was shipped from the U.S.

Through these aids and the production within the frome of the "off-shore" assistance, the European allies promoted their war industry; while also it helped their balance of payment problems.

\section{2 - Defense Support Aid}

This was a kind of economic aid for military purposes not related to the Marshall Program. It amounted about \$5 billion until 1963. It aimed at accomplishing two objectives. One of the objectives was to enforce the economics of aid-receiving countries. The other objective was to provide financial support for their defense efforts. However, this kind of aid steadily decreased in amount by time and finally lost its significance.

\section{3 - Intermediate Type Aid}

These kinds of aid were given by the U.S. to support some national programs in the allied countries. It amounted almost $\$ 1$ billion and died down by time. Neverthlese, it was continued for a time between the U.S. and some allies specially in ship-building industry within the cost-sharing formula.

These military aid programs, mostly by the U.S., have decreased by time parallel to the European economic development. However, the Defense Aids to Greece, Turkey and Portugal still continue in limited amounts from time to time, but they have no more the characteristics of grands-in-aid. Cash-paying and on credit military sales are the mapor types of Defense aids in the Treaty. As a matter of fact, sometimes, small portion of these military sales is so cheap that the payment is very nominal; but the materials delivered so seems to be outmoded (This will be taken into consideration later in the paper).

In the Treaty, there are some members which could not yet accomplish their economic development and therefor can not totally fullfil the requirements for a mutual defense. These are Greece, Portugal and most important Turkey. Greece, in later years, has recorded some positive developments and economic recovery. Portugal is also promising for the future. But the situation is not opti- 
mistic for Turkey which struggles with heavy internal affairs consisting of economic and financial difficulties. For the problems in Portugal and Turkey, the NATO allies formed an Ad Hoc Group to aid these countries militarily (France and Greece have not participated in the Group). The formation of the Ad Hoc Group within the Treaty is a positive development. Because the aids in NATO have depended upon the bilateral agreements until 1976, after the evaluation by an organ attached to the Council.

Turkey has started to receive the military assistance in limited amount upon the formation of the Group. West Germany, in November 1980, has given 600 million DM aid to Turkey. Major defense equipment will also be provided to Turkey in accordance with the agreement. Credit conditions are also in favor of Turkey.

\section{C - Economic Problems of the Treaty}

The main purpose of NATO, as defined in the Charter and practiced by the members in the inital years is to defend the Region. However, the economic and financial difficulties originated from the defense expenditures of one or more nations have taken great attention by time. Further, the Charter has also put the provision of economic cooperation and harmonization among the members.

The difficulties mentioned above can be put in two categories. One is the economic problems faced by the allies while fulfilling the requirements of the defense treaty. The other problem, related directly or indirectly with the first one, is the national arrangement of the economic relations with the member and non-member countries in such a way that the arrangements do not contradict with the spirit of the Treaty.

\section{III - MILITARY EXPENDITURES AND ITS ECONOMIC AND FINANCIAL PROBLEMS}

Since the main purpose is the defence, a "Defence Committee" meeting at least once annually, has been formed within the Council, Another committee is the "Military Committee" which consists of chief-of-staffs of the allies. As an executive committee the "Standing Group" has been formed. The "Defence, Financial and Economic Committee" and "Military Production and Supply Board" have been organized to deal with the defence materials, their production and financing defence expenditures. In the beginning, the Council and 
the affiliated agencies were not structurally complex, but fulfilled the required duties for defence purpose.

Within the NATO allies, beginning in 1950, there had been continous price increases, inflation, balance of payment problems, provision of raw materials which greatly inhibited the advance in defence efforts. To deal with these problems and search for final solutions, "Temporary Council Committee" has been formed in 1951. The duty of the Committee was the coordination and balance of collevtive security expenditures according to the political and economic capabilities of the members. The Temporary Council Committee has brought up the question of equitable distribution of collective defense expenditures and burdens among the allies to the agenda. The Committee also suggested the continuous review and evaluation of the defence programs on the basis of economic and political progress in the allied countries. This suggestion was accepted and these reviews and evaluations have later been referred as "The Annual Review".

The defence expenditures have so far been supported by the national resources and this fact was the constant source of numerous problems. There had been no serious controversy over the support of defence expenditures, in the initial years, as the American support to the European allies was in the form of grant-in-aids. Neverthless, following the recovery and the economic progress in Europe, the U.S. grand-in-aids decreased in large amount and the procedures of military sales have taken place. As a matter of fact this change in the form of assistance beginning in 1955, had negative effects on the economies of the European allies and so created the balance of payments disequilibriums. However, this kind of emerging affairs has been settled down through the understanding and trust existing among the allies; for instance some programs have been carried out collectively. This collective action has also paved the way for some allies to be acquainted with new techniques, provided some employment opportunities and improvement in the quality of the product. The collective programs have been carried out not only between the U.S. and Europe but also among the European allies. Some collective projects still continue such as Tornado aircraft program, Gazelle, Lynx, Puma helicopter programs and etc. On the other hands, the difficulties on the balance of payments, created by the military purchases among the Treaty members have been mostly eased or solved through the "Off-set Agreements". The off-set agreements mean, in short, to sell a commodity or service in return of acquisation of 
another commodity or service. It also includes free leases of some land and bases to another ally in return of some military expenditure on behalf of host nation. This sort of bilateral agreements have been existed between the U.S. and the West Germany since 1961 and between the U.K. and W. Germany since 1956. The existence of the U.S. and the U.K. forces in West Germany mainly depend on this kind of agreements. Otherwise, the U.S. and the U.K. would have withdrawn part of their stationary forces in Federal Germany.

As it was stated above, the high rate of inflation and the increasing trend of raw material prices have forced the NATO members to be more rational in defense expenditures in recent years in comparison with the past. The public sensitivity has also increased for the military spending. Therefore, there seems a great effort in the part of the allies to balance their purchases of military equipment and arms. The military purchases, particularly from the U.S., named as "twoway street" has received the outmost objection even though they were, in a sense, in the form of off-set sales. However, the U.S. reaction to the objections, which is one of the biggest problems in NATO, looks very conciliatory indeed. As a matter of fact, the Secretary of State's declaration is in the same nature and verifies the above observation :

"Europe, while willing to cooperate, has calles more of a "twoway street" in defending buying. In response, we have signed memoranda of understanding with many NATO countries to allow fair competition for the alliance-wide defense industry. We are also making major efforts to buy already-developed European equipment for U.S. use where it meets our needs at a competitive price. In addition, we are proposing to the allies that they focus their research and development spending on the production of the best equipment for the Alliance in their area of specialization.

We are already discussing with the Armament Directors of our NATO allies how to specialize in the next generation of anti-tank weapons, air-to-air missiles, and anti-ship missiles and air-to-ground weapons..."5

Sharing of the collective defense expenditure is another major problem related to the issues mentioned above, in the Alliance.

s Harold Brown, DEPARTMENT OF DEFENSE ANNUAL REPORT, FISCAL YEAR $1980, \mathrm{p}, 48$. 
One of the proposals in this respect is an equitable distribution of burden among the allies. But it presents no practicality. It seems to be that the U.S. assumes the major burden of the NATO defense expenditures. Along with this, the European allies, with some exceptions, accepted and put into pratice an annual increase of $3 \%$ in their defense spendings. The general trend shows that the European allies will proportionally increasing their shares, compared with the U.S., in the total collective defense budget (see Chart (IV). The evaluation of the U.S. Defense Department on this subject looks again reconciliatory and optimistic.

"The question of an equitable distribution of the burden in NATO's defense deserves serious attention. We have an obligation to the American people to be sure that the United States is not carrying an excessive proportion of the load. It is equally important to the vitality and efective functioning of NATO itself that the defense burden be fairly apportioned. Historically, alliance have become subject to internal fissures, and eventually cleavages, when some members began to believe that other members were not contributing adequately to the common security. We cannot aford to have such a feeling develop either here or among our allies, because our only hope for effectively confronting Soviet military power at reasonable cost is too pool our common resources.

"Preventing inequities is not a simple task, and preventing misperceptions of inequity it even more difficult. Our continental allies, for example, have maintained their peace time conscription of young men but note that we, the British and the Canadians have opted for-purely volunteer forces. Our own experience clearly establish that conscription is a burden. Some allies have pointed out what appear to them to be unusual risks accompanying their membership in the alliance, since a conflict involving NATO and founght on European soil could arise from a U.S. - Soviet confrontation elsewhere in. the world.

"Given the range of various indicatiors of economic strength within the alliance, plus the varying degrees of potential benefit to be derived from NATO, a precise calculation of equitable shares is improssible. However, when all factors and indicators are considered, I believe that the U.S. contribution is neither lavish nor parsimonious. Our attention should be focused on the difficult enough question of whether, in the aggregate, we 
are doing enough rather than simply on the nearly impossible one of whether our individual contributions are equitable."6

"Some examination of spending can be instructive. The U.S. devotes 5.4 percent of its gross domestic produot (GNP) to defense, compared to an average of around 3,7 percent for NATO Europe. But allied defense spending is on the rise; between 1970/1971 and 1976/1977 real spending by the allies increased by approximately 13 percent."

\section{IV - THE PROBLEMS DUE TO ECONOMIC COOPERATION AMONG THE MEMBER COUNTRIES}

As it has been mentioned before, the Atlantic Treaty was signed mainly for defense of the Region. While the Western European allies having recovery in their defense power, gradually the idea and desire for economic cooperation among themselves developed. In fact, the Treaty was not aimed at the unity only for military purpose. According to the Treaty, the members would also seek to developed economic, social and cultural cooperation among themselves. The subject of the economic cooperation has been noted in Article 2 of the Treaty as follows:

"Te parties will contribute toward the further development of peaceful and friendly international relations by strenghtening their free institutions, by bringing about a better understanding of the principles upon which these institutions are founded and by promoting conditions of stability and well-being. They will seek to eliminate conflict in their international economic policies and will encourage economic collaboration between any or all of them."

The main reason for the suggestion of the economic cooperation among member countries has most probably been the idea that the capacity to support defense can be preserved and developed only if it is dependent on the healthy economic structure. On this subject, Lester B. Pearson, the Canadian Statesman, has noted as follows :

"This Treaty, through born of fear and frustration, must, however, lead to positive social, economis and political achievements if it is to live."

- Ibid, p, 220-221.

7 lbid, p. 222. 
In addition to the verious economic and financial problems of the European members, the differences in their economic institutions and the legal-administrative structures which shape these institutions create problems in the Alliance. As a matter of fact, the healthy and expanding economies of the U.S.A. and Canada were also the source of unbalance in the economic relations of the members.

There was also much possibility for some other problems that could arise because of the members' relations with non-member countries and that with the ones which were colonies in the past. This subject is stated as follows:

"The political instability of certain members, chronically aggravated in some cases by inefficient and inequitable fiscal system, represents ..... hazards for NATO.

“...... NATO's prospects for greater unity and closer association lies in the conflicting economis policies of many of its members. The protectionism of Franse stands in opposition to the lower tariff aims of the Benelux countries, the greater emphasis in Nord America upon private, competitive enterprise and the allocation of resources by market forces in contrast to the inclination of many of the European partners toward state ownership and dirigisme. United States policies for disposal of its surplus of agricultural production conflict with the vital export interest of Denmark, Holland and Canada. Such differences tend to weaken the sense of unity and mutual interest which it is essential that NATO should maintain and strengthen. They are obstacles to closer economic cooperation and to steps toward economic integration."

Similar ideas and suggestions for necessary economic measures in order to maintain the functioning and the existence of the Alliance have been advanced in the later period also as it was done in the beginning.

In fact, since NATO was not primarily an economic organization it was not obliged to be concerned with the economic problems coming out as a result of their relations with the member or non-member countries and due to their internal structures as well. It is seen however that because of the desire of co-existence in an atmosphere of understanding and mutual trust existing among the members,

3 Roland S. Ritchie; NATO THE ECONOMIC OF AN ALLIANCE, Toronto, 1958, p, 138. 
common benefits have been evaluated rationally. Being realized also that powerful defense system requires healthy economic structure. an effective policy has been followed in this regard. We outline this point as follows :

Even before the liberation from occupation, Belgium, Holland and Luxemburg have signed the Benelux Treaty in London. After the liberation of Europe, the democratic and free West European countries have initiated some attempts to activate the intra-European commerce and that to solve specially the problems of the bilateral payments. The first Treaty, in this respect, has been the "Agreement on Multilateral Monetary Compensation" signed in November 1947. Such an agreement had been initiated during the negotiations for the establishment of OEEC (The Organization for European Economic Cooperation) which was organized upon G.C. Marshall's proposal aiming at the economic rehabilitation of Europe. OEEC was founded in 1948.

Some other agreements have been made to facilitate the economic and financial cooperation and that, in the meantime, to wind up the debts due to the commercial relations of the countries. The most important of these agreements in the NATO Alliance, has been the one leading the transformation of the European Coal and Steel Coommunity, first set up as a nucleus, to the form of Common Market, being effective as of March 25, 1957

France, Italy. Federal Republic of Germany and Benelux countries were the founders of this union. Later; U.K., Denmark and S. Ireland have joined the union. When Greece and Portugal also participates in it, the union will become a powerful economic integration, formed by the ten out of the thirteen European NATO members.

Furthermore, it is also understood from the practice that the NATO countries are eligible for economic and financial support from some international organizations, economic and financial in nature, which are not consisting of NATO members exclusively. The NATO countries were even given priority. Some of the most important ones of these organizations are International Monetary Fund (IMF), International Bank for Reconstruction and Development (IBRD) and Organization for Economic Cooperation and Development (OECD).

We have mentioned above some of the most important international organizations, economic and financial in nature. NATO member countries have also made serious attempts to overcome economic problems coming up due to various reasons among themselves 
and that to found cooperation in order to strengthen the Alliance. In fact, some positive developments have been achieved in this regard.

As it was noted before while some progress on the work for the solution of the military problems of NATO, the economic issues were gradually brought up with special emphasis into the agenda. The most worth mentioning activity has been the efforts in the alliance to strengthen its economy at the time when the East-West relations looked somewhat improved in 1956. That is: in May 1956, the foreign ministers of NATO met in Paris to study the "detent" that seemed to appear. In case "detent" has turned out to be true, besides the defense efforts which were the main subject of the Alliance, giving special emphasis on the economic cooperation would also be required. For this purpose the Council set up a committee consisting of three ministers (The Committee of Three) to advise on ways and means to improve non-military cooperation and so to develop the mutual reliance and greater unity in the Atlantic Community. The members of the Committee which was also named as "Three Wise Men, were Gaetano Martino, Halvand Lange, Lester B. Pearson, foreign ministers of Italy, Norway and Canada respectively.

The Council accepted the report prepared by this Committee in December 1956. The main part of the report was devoted to the political cooperation. However, it also included proposals regarding cooperation in economic, scientific, technical, cultural and information fields. In the part dealing with the economic suggestions of the Committee, it was emphasized that the economic relations had to be promoted with member countries and non-member countries of the free world as well.

The Committee also suggested the exchange of the ideas and consultation on the special subjects which could effects the economic structure of the community and influence politically.

The suggestions of the Committee, to promote the cooperation among the members and to review the economic problems of the community, led to the creation of the Economic Committee in NATO. The formation of such a committee had also been suggested at the meeting of the prime ministers held in December 1957, in Paris.

The Economic Committee since its establishment, has been working hard on the analysis of the economic issues of the NATO countries and on the possible solutions. The Committee examines and evaluates the economic resources of the member countries. It 
also studies the economic structure and functions of the countries in the East Block. In sum, it follows and evaluates the conjuncture of the world economy.

\section{V - FINAL EVALUATION WITH SOME FURTHER INDICATIONS}

The highlights of the general evaluation of the points mentioned so far are as follows:

a) At the end of the II. World War, NATO has been set up to defand the Western World against the expansionist policy of the Soviet Union in Europe.

b) Upon the establishment of NATO, the U.S.A. offered great military and economic aid to West European countries since they were in difficult economic conditions. Canada also participated in the aid partly.

c) The aid was fully in grant form in the beginning. However, after 1955, when the European countries had the economic recovery, the aid in grant form ceased.

d) The military aids, particularly the one in the form of off-shore, created the opportunities for income increase, employment possibilities and development of war industry in the European countries. It also ecouraged cooperation among the members. Some American weapons and weapon systems (i.e. Sidewinder, Bullpup missiles or F-104, F-4 aircrafts) were produced with licence in Europe through the joint programs. In later periods, the European members themselves run such joint programs (Jaguar, Lynx, MRCA-Tornado...).

e) At the beginning, U.S.A. met the major part of the defence expenditure. Gradually, the other countries stepped up their financial contributions in the budget of defence. In fact shortly after the establishment of NATO, the subject of how to share the burden of the common defence, has been brought up to the agenda. This issus has been worked on and some formula have been put into practice.

f) But, at present, the financial contributions of some members to the common defence expenditure, seem to be decreasing relatively, as it can be seen in the attached table (Table: 1). Although, by the agreement signed in 1978, the members of the alliance accepted to increase their shares 3 percent annually, it is understood that some of them have not conformed this requirment. For example, Denmark 
stated in September 1980 that she would freeze the defence expense for four years. It seems to be Belgium is going to make a similar decision.

Whereas Russia has continued to increase its military forces. For instance, West Europe is under the threat of medium range SS-20 missiles in addition to other missiles. Even so, some alliance members in this region seem indifferent to the proposal of the United States to allocate a base for Pershing II and Cruise Missiles in their countries.

g) In sum, it looks to be that because of the attitudes of disagreement of some European members of NATO, the military problems already existing in the Organization will become more serious. As a consequence, this will cause weakening of NATO which has shown rather healthy growth and that which has been effective in protecting the peace in the region, and thus, preserving the peace in the world so iar.

h) Furthermore, although it differs from country to country, the economic conditions becoming heavier, and increasing inflation may upset a great deal some of the NATO countries. In this respect, Turkey is in a very critical situation. Considering as a basis ior some of our suggestions to be made later, we shall refer here to the following statement :

"A nine member delagation of the House Armed Services Committee led by Rep. Dan Daniel ( $D-V a$ ), chairman of a sub-committee on NATO, returned from a one week inspection trip to West Germany, Italy, Belgium and Turkey, and said it was "shocked" by Turkey's "dangerously weak" position because of its obsolete military equipment."

"The most dangerous spot in Europe at present in probably Anatolian Turkey - The Turks are at the extreme end of their supply line; the Soviet have, immediately to their rear, all the logistics support they need... and there's no way the Turkish forces can be built up at any time in the near future. Estimates for a complete upgrading range up to $\$ 5$ billion, and that just for modernization. It would not really bring Turkey into the missilles-and jetfighters age." 10

9 ATLANTIC COMMUNITY NEWS, Séptember, 1979, p, 1.

15 James D. Hessman; "NATO Overview-New Challanges Facing the Alliance, THE ATLANTIC. QUATERLY, Spring, 1880, p, 47. 
As it will be understood from the above statements that there are some regions of NATO in need of support. A variety of factors has played role on this situation. It seems to be that fast improvement of the conditions in Turkey neither can be expected. As it was pointed out before, while some members did not show willingness to increase the defence expenses, some others like Turkey (in some degree Portugall could not raise the defence expenses to the desired level due to the deficiencies in their economic resurces. It is possible to give further samples in this connection.

No doubt, the economic and financial situations have influenced greatly the increase in the problems of distribution the burden of defence. As it is known the organs which make final decisions are the parliements. On the decisions of the parliements, the public opinion has great influence.

1) The European members of NATO have developed close economic cooperation as they have done in military fields. Firstly, common market united six members. Later, with the accession of U.K. and Denmark, it became a union of eight. Except Ireland, the number of the members will be ten in 1981. Norway and Iceland, out of five members of the Alliance, did not join to the community. So did not the United States and Canada, most probably because of their geographical-positions and the characteristics of their economic policy. Another member of the Alliance, namely Turkey is not able to get full association in it, since it has not yet ensured its economic stability. In the meantime it also has serious demographic problems. Turkey will probably join the Common Market after 1985.

Starting from its establishment, EEC kept economic relations increasingly with the other countries of the Alliance. Furthermore all the NATO countries are the members of OECD. This provides the opportunity for very close economic relation with both members and some other developed nations of the free world.

Turkey not being able yet to lighten its economic difficulties, has obtained support from OECD and that as a NATO member has received considerable aid from various financial organizations. For instance :

“... meeting in Guadeloupe on January 7, 1979, President Carter, President Giscard D'Estaing, Prime Minister Callaghan and Chancellor Schmidt resolved to undertake a multilateral solidarity assistance program for Turkey. The organizational fra- 
mework for this action was found within the OECD which declared its willingness to assume a key role in preparing the program."11

Doubtless, it cannot be expected that all the members of the Alliance fully cooperate in al economic affairs. In this, some factors like the nature of economic structures of some countries, public opinion and some natural factors play role.

j) However it should be taken into consideration that the member countries may face with great problems due to the economic events happening :

"In the 1980's some of the unsolved problems of the 1970's will continue to be with us. But the 1980's are also likely to present new problems, and additional stresses on the stability and well-being of Western democratic societies...

"There has developed a widespread loss of confidence among the wider publics of the Western industrialized market economy nations, with readily apparent effects in the slowdown in the rate of investment in future needs and in the development of future technologies." 12

In sum, it is clear that NATO in the near future will have to cope with the problems getting more serious in the course of time.

\section{CONCLUSION}

With the explanations we made so far, we tried here to outline in general terms, the problems in relation with the military aids and the economic cooperation, NATO has faced with during the thirty years of its development process.

After we make a general evaluation of the findigs of our study, it is natural that we have some suggestions on some points. We can note here these suggestions with the main highlights as follows :

a) Since the establishment of NATO, peace and stability have been created in the region. In this way not only the security of the

11 W.L. Kiep; "Strengthening Our Turkish Partner: Germany Spear Heading The Effort", NATO'S FIFTEEN NATION. June-July 1879, p, 19.

12 POLICY PAPER. SUMMIT MEETINGS And Collective Leadership In the 1980's. The Atlantic Council of the U.S., Washington D.C., April 1980, p, 13-14. 
Military Expenditures

5 BILLIONS ( Constant 76 )

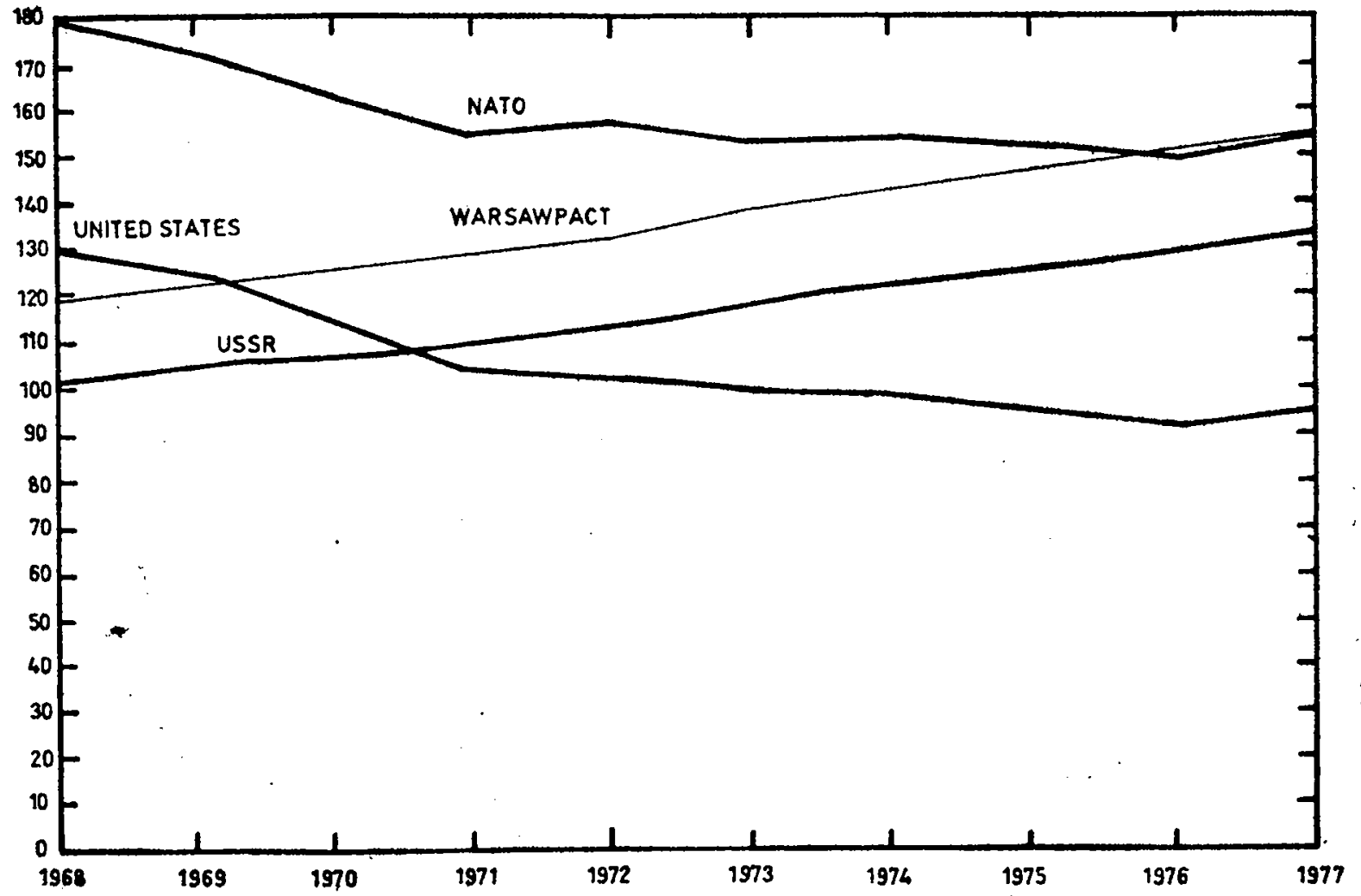

Source: WORID MILJTARY EXPENDITURES AND ARMS TRANSFERS 1968-1977. 
West Europe has been maintained, but also the economic development has been accomplished. However, it is a fact that, in time, some members of the Alliance proportionately reduced their contributions to common defence expenditures. In other words there is inequality among the merbers in sharring the burden. The United States, in particular assumes the largest share of the spending. If in distributing the burden, the per cadita G.N.P.s were taken into account, as the share of the United States was 5.4 percent in 1977, the share of the West Germany hich had almost the same per capital G.N.P. should have been more than 3.4. percent the amount being paid. In the same way, Denmark and Canada should have raised more than 2.5 percent and 2.0 percent of their contributions respectively.

b) If the economic problems (inflation, unemployment...) as some members have argued, were the determining causes to reduce the defense expenses, perhaps with this logic, Turkey the member of the Alliance with the lowest per capita G.N.P., should have abolished or at least discharged all its military forces. Definitely, it can be justified that in certain periods of political instability, like government crisis, because of the problems the countries face with and the pressure of public opinion, they may reach to a decision of decreasing the defense spendings. But since to enable NATO to assume its responsibilities fully and to function efficiently is vital for all members, the above cause concerned should be given secondary priority.

c) It is a reality that the defence of Europe cannot be without the United States. On the other hand the United States also needs Europe. For this reason the assessments on the subject of the distribution of defence expenditure should be made with mutual respect and understanding.

d) To find a formula in regard to sharing the expenses seems to be very difficult almost impossible. Although tried hard, we could not reach to a certain formula. Neverthless, it might be suitable that the shares of the contribution in the Alliance, as they have been set and accostumed, continue to be practiced in accord with the decision made in 1978. However, it should also be put into application that the countries with approximately the same per capita G.N.P. contribute to the defence expenditure in equal proportion. As a result of such practice, it is expected that the countries like Canada, Norway, Denmark, West Germany, Belgium and Italy will raise their shares, rather considerably, for defence purpose, in comparison 
Table : I

Defence expenditures in NATO countries for 1868-1977 (MILEX/GNP)

\begin{tabular}{|c|c|c|c|c|c|c|c|c|c|c|c|c|c|c|c|c|c|c|}
\hline Years & 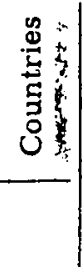 & $\begin{array}{l}0 \\
\xi \\
z \\
z\end{array}$ & 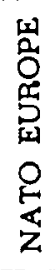 & $\dot{4}$ & 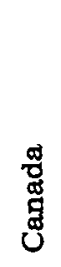 & $\begin{array}{l}\text { के } \\
3 \\
\vdots \\
0 \\
Z\end{array}$ & 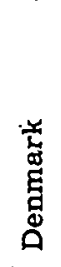 & 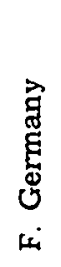 & ⿷匚⿱乛耳 & 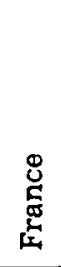 & 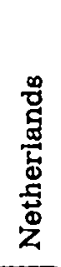 & 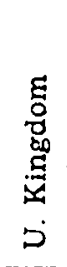 & 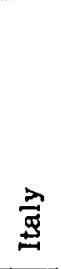 & 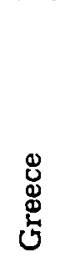 & 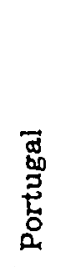 & 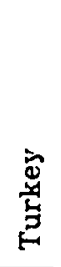 & 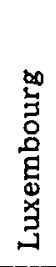 & 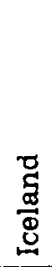 \\
\hline 1808 & & 6.8 & 4.1 & 9.3 & 2.7 & 3.6 & 2.8 & 3.6 & 3.1 & 4.9 & 3.6 & 5.3 & 3.0 & 4.6 & 6.9 & 4.6 & 1.0 & 0 \\
\hline 1869 & & 6.3 & 3.0 & 8.7 & 2.4 & 3.6 & 2.5 & 3.6 & 2.9 & 4.4 & 3.6 & 4.9 & 2.7 & 4.7 & 6.2 & 4.3 & 0.9 & 0 \\
\hline 1970 & & 5.8 & 3.7 & 7.8 & 2.4 & 3.7 & 2.4 & 3.3 & 2.9 & 4.2 & 3.5 & 4.8 & 2.7 & 4.7 & 6.5 & 4.2 & 0.8 & 0 \\
\hline 1971 & & 5.3 & 3.7 & 7.0 & 2.3 & 3.4 & 2.5 & 3.4 & 2.8 & 4.0 & 3.4 & 4.8 & 2.9 & 4.6 & 6.7 & 4.4 & 0.8 & 0 \\
\hline 1872 & & 5.1 & 3.8 & 6.6 & 2.1 & 3.3 & 2.3 & 3.5 & 2.8 & 3.9 & 3.4 & 5.1 & 3.1 & 4.4 & 6.3 & 4.1 & 0.9 & 0 \\
\hline 1873 & & 4.7 & 3.4 & 6.0 & 2.0 & 3.2 & 2.1 & 3.5 & 2.7 & 3.8 & 3.2 & 4.8 & 2.9 & 4.0 & 5.4 & 3.9 & 0.8 & 0 \\
\hline 1874 & & 4.8 & 3.7 & 6.1 & 2.0 & 3.1 & 2.4 & 3.6 & 2.7 & 3.7 & 3.3 & 5.0 & 2.8 & 4.1 & 6.8 & 3.7 & 0.8 & 0 \\
\hline 1875 & & 4.8 & 3.8 & 5.8 & 1.9 & 3.3 & 2.6 & 3.6 & 3.0 & 3.9 & 3.5 & 5.0 & 2.7 & 6.3 & 4.9 & 4.4 & 1.0 & 0 \\
\hline 1976 & & 4.4 & 3.7 & 5.4 & 1.9 & 3.2 & 2.5 & 3.5 & 3.2 & 3.8 & 3.3 & 5.0 & 2.6 & 5.3 & 3.7 & 5.5 & 1.1 & 0 \\
\hline 1877 & & 4.5 & 3.7 & 5.4 & 2.0 & 3.1 & 2.5 & 3.4 & 3.2 & 3.8 & 3.6 & 4.8 & 2.7 & 4.6 & 3.3 & 5.7 & 1.1 & 0 \\
\hline $\begin{array}{c}\text { GNP } \\
\text { in U.S. } \$ \\
\text { (1877) }\end{array}$ & & 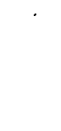 & • & 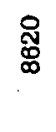 & 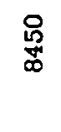 & 윯 & 융 & $\underset{0}{\stackrel{8}{0}}$ & $\begin{array}{l}\stackrel{8}{0} \\
\text { م } \\
\text { م }\end{array}$ & 怘 & $\stackrel{8}{9}$ & 옳 & 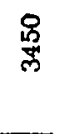 & 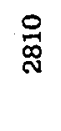 & $\begin{array}{l}\text { 오 } \\
\text { Ф્ન }\end{array}$ & 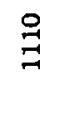 & 옥 & 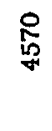 \\
\hline $\begin{array}{l}\text { GNP/p.c. } \\
\text { indices } \\
\text { U.S. }=100 \text { ) }\end{array}$ & & & & 8 & $\begin{array}{l}\circ \\
\stackrel{8}{\$}\end{array}$ & $\overrightarrow{\mathscr{B}}$ & $\stackrel{\infty}{\infty}$ & $\vec{\infty}$ & 嗢 & $\stackrel{\infty}{\mathbb{\infty}}$ & $\overrightarrow{\mathbb{D}}$ & in & $\stackrel{\circ}{\circ}$ & $\begin{array}{l}0 \\
\text { న్ }\end{array}$ & $\stackrel{n}{-10}$ & 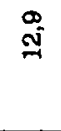 & $\begin{array}{l}\infty \\
\text { న్ } \\
\text { d. }\end{array}$ & 1 \\
\hline
\end{tabular}

Source : Compiled from WORLD MILITARY EXPENDITURES AND ARMS TRANSFERS 1868-1977, United States Arms Control and Disarmament Agency, October, 1979, Washington D.C. pp 28-65. (GNP/p.c. in U.S. Compiled from WORLD DEVELOPMENT REPORT 1978, World Bank, August, 1879, pp. 126-127). 
with the present level. It must be borne in mind that the Warsaw Pact members allocate more than ten percent of their G.N.P.s for military spendings. For this reason, the possible arguments about self sacrifice of the NATO members should not be considered valid. The good will and mutual dependence continue in case the members go on acting with devotion. In short, the European members and Canada should raise the amounts of their contributions for defense expenditure for the Alliance.

e) On the other hand, in the Alliance, there is a member which is struggling with serious economic problems and even though making relatively high expenses for military purposes. As it was pointed out before, in order to be able to carry out her responsibilities of defence, Turkey needs sufficient amount of weapons and materials. Whereas this country for a long while, has been buying most of these materials on cash payment. She gets very few through grants. As a result, the capacity of Turkey to support the defence efforts is far below the ideal level. If this country is expected to assume its responsibility properly, the military aid in the form of "gyant" in broad dimension is definitely a necessity. We are of the opinion that specially Germany and Canada should participate with the largest shares in this kind of aid.

g) It is suitable and a "must" as well, that the joint programs held so far, be continued in the future. In addition to the economic and financial opportunities created through such projects, we also acknowledge the benefits of these projects by which the transfer of the technologic development will be possible to the countries, specially to Turkey, Greece and Portugal. Participation of these countries, for instance in the joint program between the United States and Belgium, Holland, Denmark, Norway to produce F-16 lightweight fighter will be very useful.

g) To introduce and inform the public of the weapon systems produced through these joint programs has also vital importance to influence the public. For instance, serious criticism and propaganda with certain intentions againts NATO are carried on in some member countries. Whereas, in such countries, the industry being able to undertake the production of modern weapons, even though in partnership, will influence positively the public of these countries.

h) The problems coming out of the economic cooperation among the NATO members do not appear to be unsolveable. It is true that industrial and commercial competence in liberal economies is a ba- 
sic requirement. However, in a community set up for common aims, the economic cooperation also brings forward many advantages. Actually, close cooperation and relations have already been going on among NATO members as well as between the NATO members and outside NATO countries of the free world. Furhermore, some member countries can get the support and aid they need from the organizations like OECD, IMF, etc. For this reason, it is not necessary to add more to this subject.

In conclusion, it should be pointed out that NATO has survived for more than thirty years, had dynamics for growth and that the most important of all, has been effective excessively in preserving the peace in the world. Naturally, some problems may come out in this structure. But it seems to be that, these difficulties will be overcome by mutual understanding, trust and reliance and that NATO will continue to assume with success its essential responsibilities in the future. 